\title{
Generating Human DNA Profile(s) from Cell Phones for Forensic Investigation
}

Khalid Mahmud Lodhi ${ }^{1 *}$, Robert Grier IV ${ }^{2}$, Sabrina Davis ${ }^{1}$, Stefanie Phillips ${ }^{3}$ and Mohammad Atif Lodhi ${ }^{4}$

${ }^{1}$ Biological Sciences, Fayetteville State University, Fayetteville, NC 28301, USA

${ }^{2}$ Mathematics and Health Professions, Atlanta Metropolitan State College, Atlanta, GA, USA

${ }^{3}$ Education Center of Moore County Schools, K-12 Curriculum Specialist, 160 Pinckney Road Carthage, NC 28327, USA

${ }^{4}$ Fayetteville State University Graduate Student, Campbell University, PO Box 70659, Fort Bragg, NC 28307, USA

"Corresponding author: Khalid Mahmud Lodhi, Biological Sciences, Fayetteville State University, Fayetteville, NC 28301, USA, Tel: 910-672-1650; Fax: 910-672-1159; E-mail: klodhi@uncfsu.edu

Rec date: April 28, 2015 Acc date: May 19, 2015 Pub date: May 24, 2015

Copyright: () 2015 Lodhi KM, et al. This is an open-access article distributed under the terms of the Creative Commons Attribution License, which permits unrestricted use, distribution, and reproduction in any medium, provided the original author and source are credited.

\begin{abstract}
The goals of this study were to investigate whether sufficient amount of human DNA can be recovered from a cell phone and if the identity of the single and/or multiple user(s) can be established by generating genetic profile(s). Cell phones were used to collect human DNA. Two Buccal swabs were used to collect Buccal cells as a DNA reference samples. Four soaked sterile cotton swabs were used to collect biological materials from each user's cell phone. Sufficient quantity and quality of human genomic DNA was obtained from the cell phones using Quantifiler® Human DNA Quantitation Kit. More human DNA was collected from volunteers' Buccal swabs (=74.56 ng) than from the surface of their cell phones $(=0.23 \mathrm{ng})$. One nanogram $(1 \mathrm{ng})$ of template DNA was used for buccal swabs and cell phones swabs, if available. However, when the DNA recovered from cell phone swabs was 0.00 to $500 \mathrm{pg}, 10 \mu \mathrm{L}$ of template DNA was used. In addition, the number of PCR cycles was increased from 28 to 32 in anticipation of Low Copy Number DNA. Genetic profiles were developed from the DNA on the cell phones and were compared with the reference DNA profiles from the buccal cells of the cell phone owners. Full Short Tandem Repeats (STR) DNA profiles for all 15 STR loci plus Amelogenin locus were typed for 36 Buccal swabs, reference DNA of cell phone owners. Complete STR profiles were generated from $33 \%(\mathrm{~N}=36)$ cell phones and were matched participants'. In addition, $28 \%$ of cell phones had partial DNA profiles matched with the cell phone owners. While, $33 \%$ of the cell phones had unknown partial or complete profiles. Four of the unknown partial profiles had more than two alleles at the STR loci indicating multiple unknown cell phone users. The $Y$ chromosome was detected at the Amelogenin locus from the DNA profiles generated from two females' cell phones identifying unknown male contributor(s). Our study demonstrates that DNA collected from the cell phones can be used as reliable physical evidence in forensic investigations.
\end{abstract}

Keywords: Forensic science; Genetic profile; Cell phone; STR; Human DNA; Partial profile; Y Chromosome; LCN; DNA; Buccal swabs

\section{Introduction}

In December 2012, there were 326.4 million cell phone subscribers in the United States (US) [1]. In perspective, the 2010 resident population of the USA was 309 million [2]. Clearly, the number of cell phones in use is significantly more in comparison to the US resident population. Based on the previous data about the number of cell phone in use it should not be surprising that cell phones are also used in criminal activities. Forensic investigation of cell phones has focused on the digital information stored in the cell phone such as text messages, pictures, calls sent and received [3-5]. This digital information in the cell phone is used to track the movements of the cell phone user(s) and establish a time line of events preceding or following a criminal activity [4]. Unfortunately, the digital information stored in a cell phone does not provide identity of the actual cell phone user(s). For example, how many different individuals have used the cell phone? Did the owner of the cell phone use it or someone else?

The standard procedure for generating genetic profiles from forensic evidence is to use Short Tandem Repeats (STRs) Polymerase Chain Reaction (PCR) when the amount of Deoxyribose Nucleic Acid
(DNA) evidence is 1.0-2.5 ng [6] such as in burglary, rape and murder cases [7-11]. The manufacturer recommended PCR protocol of 28 cycles is most often used. Recently, the sensitivity of the forensic DNA analysis technique has increased; hence, a lower amount of human DNA evidence can be detected and possibly full or partial STR profile(s) can be generated [6]. When someone touches an object epithelial cells are deposited. These epithelial cells can be collected from myriad objects such as tools, weapons, and fingerprints handled by individuals during normal usage. The amount of DNA obtained from touching an object is typically less than $100 \mathrm{pg}[6,12]$. This DNA is referred to as touch DNA or low copy number (LCN) DNA [13-18], and was first used for forensic purposes in the United Kingdom in 1999 [19].

The goals of our study were to investigate whether sufficient amount of DNA can be recovered from a cell phone and if the identity of the single and/or multiple user(s) can be established by generating genetic profile(s).

\section{Materials and Methods}

\section{Extraction and quantitation of human DNA}

Thirty-six cell phone owners, seven (7) males and twenty nine (29) females, were recruited for the study at Fayetteville State University, 
Page 2 of 5

Fayetteville, NC. Each cell phone owner was provided a Buccal swab (Kendall Q-Tips) to collect Buccal cells as a DNA reference, and to compare it with his/her cell phone's DNA profile, if generated. Buccal swabs were first pre-treated for DNA extraction with $500 \mu \mathrm{L}$ of digestion buffer (10 mM Tris- $\mathrm{HCl}, 10 \mathrm{mM}$ EDTA, $50 \mathrm{mM} \mathrm{NaCl}, 2 \%$ SDS and $100 \mu \mathrm{g}$ proteinase $\mathrm{K}$ ) and incubated at $56^{\circ} \mathrm{C}$ for a minimum of three hours. Subsequently, DNA was extracted from each sample using phenol: chloroform: isoamyl alcohol (25:24:1) [20]. The Buccal swab DNA samples were concentrated using an Ultracel-100K column (Millipore, Billerica, MA). Buccal swabs were also obtained from the investigators to monitor any possible DNA contamination.

For recovering DNA from the cell phones, investigators used four cotton swabs soaked in water: two cotton swabs on the front of the cell phone and two on the back. The use of four cotton swabs is deemed important because it enhances the potential collection of biological material from different sites on the cell phone. Afterwards, the cotton swabs were air dried for 1-2 hours at room temperature and then stored at $4^{\circ} \mathrm{C}$. All human DNA present on the cell phones was deposited as a result of normal usage (i.e. no technique was used during the study to deposit any biological material onto the cell phones). All four swabs from a single cell phone were combined for DNA extraction. DNA extraction from cell phone swabs was identical to the technique used for buccal swabs; however, in anticipation of LCN DNA the protocol was modified to increase the amount of DNA recovered from a cell phone swab. The phenol: chloroform extraction step was modified by adding an equal volume of TE pH $7.5(10 \mathrm{mM}$ Tris- $\mathrm{HCl}$ and $10 \mathrm{mM} \mathrm{EDTA}$ ) to the organic phase followed by mixing, separation, and collection of the aqueous phase. The second supernatant was combined with the first supernatant collected. The additional collection increased the amount of DNA collected from the cell phone swabs. The cell phone swab DNA samples were concentrated with a Microcon-30K (Millipore) to a final volume of 12-15 $\mu \mathrm{L}$. Buccal swab and cell phone samples were then quantified with the Quantifiler Human DNA Quantitation Kit (Applied Biosystems, Foster City, CA) using the manufacturer's recommended protocol on the ABI 7500 Real-Time PCR System (Applied Biosystems, Foster City, CA).

\section{PCR Amplification}

The PCR reactions were prepared according to the manufacturer's recommended protocol using the AmpFlSTR ${ }^{\circledR}$ IdentifilerFiler $^{\bullet}$ Kit (Applied Biosystems, Foster City, CA). One nanogram (1 ng) of template DNA was used for buccal swabs and cell phones swabs, if available, and followed standard amplification protocol of 28 cycles. However, when the DNA recovered from cell phone swabs was 0.00 to $500 \mathrm{pg}, 10 \mu \mathrm{L}$ of template DNA was used. In addition, the number of PCR cycles was increased from 28 to 32 in anticipation of LCN DNA. PCR reagents were loaded into a 96-Well GeneAmp PCR System
9700 (Bio-Rad, Hercules CA) for PCR amplification. All amplification reactions were accompanied by negative and positive controls.

\section{Detection of STR Alleles}

Following PCR amplification, the ABI PRISM ${ }^{\circledR} 310$ Genetic Analyzer Applied Biosystems, Foster City, CA) was employed for electrophoretic separation of amplified products. For ABI 310 sample preparation, $24.5 \mu \mathrm{L}$ Hi-DiTM Formamide (Applied Biosystems, Foster City, CA), $0.5 \mu \mathrm{L}$ GeneScanTM 500 LIZ ${ }^{\circledR}$ Size Standard (Applied Biosystems, Foster City, CA), and $1 \mu \mathrm{L}$ of PCR amplified product or AmpFISTR $^{\bullet}$ IdentifilerTM Allelic Ladder (Applied Biosystems, Foster City, CA) were added to each sample. The reaction tubes were heated at $95^{\circ} \mathrm{C}$ for a three-minute denaturation step, immediately snap-cooled on a freezer block for three minutes, and then subjected to capillary electrophoresis. The samples were separated on a $47 \mathrm{~cm} \times 50 \mu \mathrm{m}$ capillary tube (Applied Biosystems, Foster City, CA).

Amplified products were electrokinetically injected for five seconds and fractionated on an ABI Prism ${ }^{\bullet} 310$ Genetic Analyzer using POP4 (Applied Biosystems, Foster City, CA). Data was analyzed using a peak detection threshold of 100 relative fluorescence units (RFU) for all dyes with GeneMapper ${ }^{\oplus}$ ID v3.2.1 (Applied Biosystems, Foster City, CA) which was used for data collection and analysis. The Institutional Review Board (IRB) proposal for this study was approved by the Fayetteville State University Human Rights in Research Committee (IRB \# 2009-P-032).

\section{Results}

As expected, more human DNA was collected from volunteers' Buccal swabs $\left(\mathrm{X}^{-}=74.56 \mathrm{ng}\right)$ than from the surface of their cell phones $\left(\mathrm{X}^{-}=0.23 \mathrm{ng}\right)$. The amount of DNA collected from cell phones varied from $0.00 \mathrm{ng}$ to $3.34 \mathrm{ng}$ of DNA. Differences in the amount of DNA obtained from cell phones owned by males and females were not statistically significant (data not shown).

Full STR profiles for all 15 STR loci plus Amelogenin locus were typed for 36 Buccal swabs (reference DNA of cell phone owners). However, only $33 \%$ complete DNA profiles from cell phones were matched with the cell phone owners (Table 1). A match indicates that the cell phone owner's 15 STR markers were found on their respective cell phone. Twenty eight percent of these cell phones had partial DNA profiles matching with the cell phone owners (Table 2). A partial match is defined as two or more STR markers matched with the respective cell phone owner's profile. In addition, 33\% unknown partial profiles at two or more loci were detected from cell phones (Table 3). Fourteen percent of the female cell phones a Y chromosome (112 bp) was detected at the Amelogenin locus (Table 4), identifying an unknown male contributor.

\begin{tabular}{|l|l|l|}
\hline No. & Sample Name & Results \\
\hline 1 & C3 & Complete profile, 15 loci from the cell phone matches with the DNA of the cell phone owner \\
\hline 2 & C4 & Complete profile, 15 loci from cell phone DNA matches the DNA of cell phone owner \\
\hline 3 & C5 & Complete profile, 15 loci from cell phone DNA matches the DNA of cell phone owner \\
\hline 4 & C7 & Complete profile, 15 loci from cell phone DNA matches the DNA of cell phone owner \\
\hline 5 & C9 & Complete profile, 15 loci from cell phone DNA matches the DNA of cell phone owner \\
\hline
\end{tabular}


Citation: Lodhi KM, Grier R, Davis S, Phillips S, Lodhi MA (2015) Generating Human DNA Profile(s) from Cell Phones for Forensic Investigation.

\begin{tabular}{|l|l|l|}
\hline 6 & C12 & Complete profile, 15 loci from cell phone DNA matches the DNA of cell phone owner \\
\hline 7 & C13 & Complete profile, 15 loci from cell phone DNA matches the DNA of cell phone owner \\
\hline 8 & C16 & Complete profile, 15 loci from cell phone DNA matches the DNA of cell phone owner \\
\hline 9 & C20 & Complete profile, 15 loci from cell phone DNA matches the DNA of cell phone owner \\
\hline 10 & C23 & Complete profile, 15 loci from cell phone DNA matches the DNA of cell phone owner \\
\hline 11 & C28 & Complete profile, 15 loci from cell phone DNA matches the DNA of cell phone owner \\
\hline 12 & C33 & Complete profile, 15 loci from cell phone DNA matches the DNA of cell phone owner \\
\hline
\end{tabular}

Table 1: Shows complete genetic profiles (15 loci) generated from the cell phones $(\mathrm{C})$. Genetic profile from the cell phone matched with the genetic profile of it's cell phone owner.

\begin{tabular}{|c|c|c|}
\hline No. & Sample name & Results \\
\hline 1 & C15 & Partial profile, 5 loci from the cell phone matches with the DNA of the cell phone owner matching cell phone owner \\
\hline 2 & $\mathrm{C} 17$ & Partial profile, 10 loci from the cell phone matches with the DNA of the cell phone owner matching cell phone owner \\
\hline 3 & C18 & Partial profile, 7 loci from the cell phone matches with the DNA of the cell phone owner matching cell phone owner \\
\hline 4 & $\mathrm{C} 24$ & Partial profile, 12 loci from the cell phone matches with the DNA of the cell phone owner \\
\hline 5 & $\mathrm{C} 25$ & Partial profile, 13 loci from the cell phone matches with the DNA of the cell phone owner matching cell phone owner \\
\hline 6 & $\mathrm{C} 26$ & Partial profile, 6 loci from the cell phone matches with the DNA of the cell phone owner matching cell phone owner \\
\hline 7 & $\mathrm{C} 27$ & Partial profile, 8 loci from the cell phone matches with the DNA of the cell phone owner matching cell phone owner \\
\hline 8 & $\mathrm{C} 29$ & Partial profile, 4 loci from the cell phone matches with the DNA of the cell phone owner matching cell phone owner \\
\hline 9 & C31 & Partial profile, 14 loci from the cell phone matches with the DNA of the cell phone owner matching cell phone owner \\
\hline 10 & $\mathrm{C} 32$ & Partial profile, 5 loci from the cell phone matches with the DNA of the cell phone owner matching cell phone owner \\
\hline
\end{tabular}

Table 2: Shows partial genetic profiles (loci<15) generated from cell phones $(C)$. Partial genetic profile had 2 or more loci that matched with the genetic profile of its cell phone owner.

\begin{tabular}{|c|c|c|}
\hline No. & Sample Name & Results \\
\hline 1 & $\mathrm{U}-\mathrm{C} 3$ & Partial profile, 9 loci from unknown DNA contributor(s) \\
\hline 2 & $\mathrm{U}-\mathrm{C} 4$ & Partial profile, 6 loci from unknown DNA contributor(s) \\
\hline 3 & U-C5 & Partial profile, 12 loci from unknown DNA contributor(s) \\
\hline 4 & $\mathrm{U}-\mathrm{C} 7$ & Partial profile, 3 loci from unknown DNA contributor(s) \\
\hline 5 & U-C9 & Partial profile, 11 loci from unknown DNA contributor(s) \\
\hline 6 & $\mathrm{U}-\mathrm{C} 12$ & Partial profile, 12 loci from unknown DNA contributor(s) \\
\hline 7 & U-C16 & Complete profile, 15 loci from unknown DNA contributor(s) \\
\hline 8 & $\mathrm{U}-\mathrm{C} 25$ & Partial profile, 4 loci from unknown DNA contributor(s) \\
\hline 9 & $\mathrm{U}-\mathrm{C} 27$ & Partial profile, 6 loci from unknown DNA contributor(s) \\
\hline 10 & $\mathrm{U}-\mathrm{C} 28$ & Partial profile, 2 loci from unknown DNA contributor(s) \\
\hline 11 & $\mathrm{U}-\mathrm{C} 31$ & Partial profile, 6 loci from unknown DNA contributor(s) \\
\hline
\end{tabular}




\begin{tabular}{l|l|l}
\hline 12 & U-C33 & Partial profile, 6 loci from unknown DNA contributor(s)
\end{tabular}

Table 3: Shows partial unknown (U) genetic profiles (loci < 15) and complete unknown (U) genetic profile (15 loci) generated from cell phones (C). The genetic profile from the cell phone did not match with the genetic profile of its cell phone owner.

\begin{tabular}{|c|c|c|c|c|}
\hline No. & Sample Name & Gender of Cell Phone Owner & Amelogenin & Results \\
\hline 1 & C3 & Female & $X>Y$ & $\begin{array}{l}\text { Complete profile, } 15 \text { loci from cell phone } \\
\text { matches with the DNA of the cell phone } \\
\text { owner }\end{array}$ \\
\hline 2 & $\mathrm{C} 12$ & Female & $X>Y$ & $\begin{array}{l}\text { Complete profile, } 15 \text { loci from cell phone } \\
\text { matches with the DNA of cell phone } \\
\text { owner }\end{array}$ \\
\hline 3 & C16 & Female & $X>Y$ & $\begin{array}{l}\text { Complete profile, } 15 \text { loci from cell phone } \\
\text { matches with the DNA of cell phone } \\
\text { owner }\end{array}$ \\
\hline 4 & $\mathrm{C} 24$ & Female & $X>Y$ & $\begin{array}{l}\text { Partial profile, } 12 \text { loci from an unknown } \\
\text { DNA contributor }\end{array}$ \\
\hline 5 & $\mathrm{C} 25$ & Female & $X>Y$ & $\begin{array}{l}\text { Partial profile, } 13 \text { loci from an unknown } \\
\text { DNA contributor }\end{array}$ \\
\hline
\end{tabular}

Table 4: The Amelogenin locus, $\mathrm{Y}$ chromosome $(\mathrm{X}>\mathrm{Y})$ was detected from the cell phones $(\mathrm{C})$ owned by females.

The negative control was a cell phone cleaned with four moist cotton swabs followed by exposure to ultraviolet light overnight. The next day the cell phone was swabbed for DNA collection. All cell phones cleaned in this manner did not yield human DNA. Also, the genetic profile of all investigators was compared with the unknown DNA profiles obtained from the cell phones (data not shown).

\section{Discussion}

Biological evidence can be collected from the cell phone by simply rubbing the surface with a wet cotton swab then isolating and concentrating the DNA using molecular biology techniques. No tests were conducted to identify type and source of the biological materials.

This paper establishes several important findings. First, cell phones can be used as a source to collect human DNA, and subsequently used for forensic investigations. Second, the amount (1 ng) and quality of human DNA collected from cell phones is sufficient for amplification of the 15 loci necessary to identify the individual who regularly uses the cell phone. Third, partial DNA profiles of unknown cell phone user(s) can be detected from the cell phone. The detection of unknown contributors (more than 2 alleles at a locus) demonstrates the usefulness of human DNA collected from a cell phone in a forensic investigation. Most likely the partial DNA profiles are due to LCN and/or degradation of DNA collected from the cell phone. These missing markers/allele(s) are possibly due to locus and/or an allele drop out. The possibility exists that increasing the cycle number from 28 to 32 for the cell phone DNA samples may have resulted an allele drop-in. However, these possible false alleles would not interfere with the cell phone DNA analysis because the RFU threshold is high enough $(\mathrm{RFU}=100)$ to reject an incorrect interpretation of allele scoring. Therefore, the investigator should be careful when analyzing results and consider using the miniFiler amplification kit. Fourth, in scenarios where the owner of the cell phone is female, a male user can be detected by the presence of the Y chromosome allele (Table 4). Subsequent interviews with female cell phone owners in which the $\mathrm{Y}$ chromosome allele was detected revealed that males did use their cell phones. To establish the male contributor, a genetic profile can be developed using the Y STR profiler kit and/or by generating STR profile(s) from reference samples of the male contributor.

This study demonstrates that it is possible to obtain sufficient quantity and quality of human DNA from cell phones for amplification to generate genetic profiles of known and unknown individual(s) from a cell phone. The amount of collected DNA from cell phones varied from $0.00 \mathrm{ng}$ to $3.34 \mathrm{ng}$. The biological source of the DNA on the cell phones is unknown. A possible explanation for the large amount of DNA (3.34 ng) on some cell phone may be the cell phone usage habits of the cell phone user(s), as well as other biological materials deposited on the cell phone such as saliva and/or blood of cell phone user(s). The unknown profiles in this study were all partial profiles which may be due to low amounts or degradation of DNA. Furthermore, the matching of $33 \%$ of cell phone profiles is significant based on previous research by the authors investigating latent fingerprints on cell phones [21]. In that study only $11 \%$ of the latent fingerprints lifted from the cell phones could be matched with the cell phone owners.

\section{Conclusion}

This study demonstrates that sufficient human DNA quantity and quality can be recovered from a cell phone to generate partial or full human STR profile for forensic investigations. Through the electronic and subscription record, tracking the owner of the cell phone is not a difficult job for the law enforcement agencies. However, exclusion or inclusion of the owner at the crime scene could be established through DNA fingerprints in the courtroom. Regardless of the source (epithelial cells, saliva, or blood) of human DNA on cell phone, cell phone at the crime scene could be a valuable piece of forensic evidence. 
Citation: Lodhi KM, Grier R, Davis S, Phillips S, Lodhi MA (2015) Generating Human DNA Profile(s) from Cell Phones for Forensic Investigation.

Page 5 of 5

\section{Acknowledgement}

The authors would like to thank the financial support of Dr. Daniel Okunbor, Director Fayetteville State University (FSU) Innovative Curriculum Approach for Mathematics and Science and Fayetteville State University's North Carolina Louis Stokes Alliance for Minority Participation, FSU who kindly purchased some supplies through his NSF grant to fund this research project. Both programs were funded by grants from the National Science Foundation. Also, the support of Kenan Institute, University of North Carolina, Raleigh and, Dr. Alexander Umantsev, PI U.S. Army's Research \& Engineering Apprenticeship Program (REAP), an initiative of the Army Educational Outreach Program (AEOP) administered by the Academy of Applied Science (AAS) in Boston, MA. Special thanks to Richard B. Bazzelle and La Nisha T. Gittens, (Fayetteville State University, Fayetteville, NC) for their contributions in recruiting participants and for collecting and cataloging samples.

\section{References}

1. Wireless Quick Facts [Internet]. Washington DC; CITA (2003) - The Wireless Association.

2. U.S. Census Bureau Announces 2010 Census Population Counts Apportionment Counts Delivered to President. Washington DC; December 21, 2010

3. Thing VLL, Ng K-Y, Chang E-C (2010) Live memory forensics of mobile phones. Digital Investigation 7: S74-S82.

4. Ahmed R, Dharaskar RV (2008) Mobile forensics: an overview, tools, future trends and challenges from law enforcement perspective. In: 6th International Conference on EGovernance, ICEG, Emerging Technologies in E-Government, M-Government 312-323.

5. Kim K, Hong D, Chung K, Ryou JC (2007) Data acquisition from cell phone using logical approach. In: Proceedings of world academy of science, engineering and technology 26.

6. Li R (2008) Forensic Biology. Boca Raton (FL), CRC Press.
7. Houck M, Houck L (2008) What is touch DNA? [Internet]. New York (NY): Sci Am.

8. Wickenheiser RA (2008) Trace DNA: a review, discussion of theory, and application of the transfer of trace quantities of DNA through skin contact. J Forensic Science 47: 442-450.

9. Van Oorschot RAH, Jones MK (1997) DNA fingerprints from fingerprints. Nature 387: 767-768.

10. Van Oorschot RAH, Jones MK (1997) DNA fingerprinting from single cells. Nature 389: 555-556.

11. Bright A, Petricevic SF (2004) Recovery of trace DNA and its application to DNA profiling of shoe insoles. Forensic Sci International 145: 7-12.

12. Butler JM (2005) Forensic DNA Typing, Second Edition Biology, Technology, and Genetics of STR Markers. (2ndedn) Burlington (MA): Elsehiver Academic Press.

13. Lowe A, Murray C, Whitaker J, Tully G, Gill P (2002) The propensity of individuals to deposit DNA and secondary transfer of low level DNA from individuals to inert surfaces. Forensic Sci. International 129: 25-34.

14. Barash M, Reshef A, Brauner P (2010) The use of adhesive tape for recovery of DNA from crime scene items. J Forensic Science 55: 1058-1067.

15. Bond JW (2007) Value of DNA evidence in detecting crime. J Forensic Science 52: 128-136.

16. Phipps M, Petricevic S (2007) The tendency of individuals to transfer DNA to handled items. Forensic Sci. International 168: 162-168.

17. Bond J, Hammond C (2008) The value of DNA material recovered from crime scenes. J Forensic Science 53: 797-801.

18. Perret X, Broughton W (1997) DNA fingerprints from fingerprints. Nature 387: 767.

19. Lowe A, Murray C, Richardson P, Wivell R, Gill P (2003) Use of low copy number DNA in forensic inference. International Congress Series 1239: 799-801.

20. Sambrook J, Russell DW (2001) Molecular Cloning, (3rdedn) Cold Spring Harbor, NY: Cold Spring Harbor Press.

21. Khalid M Lodhi, Sabrina A Davis, Robert L Grier, Angela B Saxon (2013) The Identification of Cell Phone Users from Latent Fingerprints. J of Forensic Identification 63: 41-45. 